\section{Normocalcemic primary hyperparathyroidism in clinical practice: an indolent condition or a silent threat?}

\author{
Hiperparatireoidismo primário normocalcêmico na prática \\ clínica: condição indolente ou ameaça silenciosa?
}

Thyciara Fontenele Marques', Renata Vasconcelos', Erik Diniz', Daniela Rêgo', Luiz Griz', Francisco Bandeira'

\begin{abstract}
Objective: To describe the characteristics of normocalcemic primary hyperparathyroidism (NPHPT) in patients seen for osteoporosis evaluation. Patients and methods: We examined the records of 156 women who came to the hospital to be screened for osteoporosis. Measurements of total calcium, PTH, 25-hydroxy vitamin D, and $\beta$-C-telopeptide were recorded. Bone mineral density and T-scores were evaluated by densitometry of the lumbar spine, femoral neck and distal one-third of the radius. The latter was only measured in patients with primary hyperparathyroidism. Nephrolithiasis and bone fractures were documented by a review of the medical records. Results: We identified 14 patients with NPHPT, accounting for $8.9 \%$ of the population studied. In the medical records, the occurrence of kidney stones was reported in $28.6 \%$ of the patients with NPHPT, in contrast with only $0.7 \%$ of the noncarriers. Regarding the presence of general fractures, $21.4 \%$ of the patients with NPHPT were affected versus $16.2 \%$ of noncarriers. Conclusion: Data from our study suggest that NPHPT has a diverse phenotypic presentation, implying that this may not be an "indolent" disease. Arq Bras Endocrinol Metab. 2011;55(5):314-7
\end{abstract}

Keywords

Normocalcemic hyperparathyroidism; osteoporosis; fractures; kidney stones

\section{RESUMO}

Correspondence to:

Divisão de Endocrinologia,

Hospital Agamenon Magalhães,

Universidade de Pernambuco,

Estrada do Arraial, 2723

52021-380- Recife-PE, Brazil

fbandeira@gmail.com

Received on Nov/12/2010

Accepted on May/25/2011

\begin{abstract}
Objetivo: Avaliar as características do hiperparatireoidismo primário normocalcêmico (HPTPN) em pacientes atendidos para avaliação de osteoporose. Pacientes e métodos: Foi realizada análise de um banco de dados de 156 mulheres que procuraram atendimento para avaliação de osteoporose. Todas apresentavam dosagem de cálcio sérico, PTH, 25-hidroxi-vitamina D e C-telopeptídeo. A densidade mineral óssea e escore-T foram avaliados por meio de densitometria óssea de coluna lombar, colo do fêmur e rádio distal, este último apenas em pacientes com hiperparatireoidismo renal primário. Nefrolitíase e fraturas ósseas foram documentadas pela revisão dos prontuários. Resultados: Foram identificadas 14 pacientes com HPTPN, correspondendo a 8,9\% da população estudada. Nos registros médicos, o relato da existência de litíase renal ocorreu em $28,6 \%$ dos portadores de HPTN em contraste com apenas $0,7 \%$ nas mulheres não portadoras, com um $\mathrm{p}<0,001$. Conclusão: Os dados do estudo sugerem que HPTPN tem uma apresentação fenotípica variada, podendo não ser uma patologia “indolente". Arq Bras Endocrinol Metab. 2011;55(5):314-7

Descritores

Hiperparatireoidismo normocalcêmico; osteoporose; fraturas; cálculo renal
\end{abstract}

\section{INTRODUCTION}

$\mathrm{N}$ ormocalcemic primary hyperparathyroidism (NPHPT), which is characterized by persistently normal serum calcium levels despite high levels of parathyroid hormone $(\mathrm{PTH})$, is an entity that has been arousing considerable scientific interest. This term was 
first used in 1960 by Wills, who described a group of patients with characteristics different from those with classic primary hyperparathyroidism (1). In this situation, a thorough search for causes of secondary hyperparathyroidism, in particular 25-hydroxy vitamin $\mathrm{D}$ deficiency, is imperative (2).

Studies on the evaluation of this specific population are scarce, especially since there is no routine measurement of PTH. As a result, there are few data on the impact of this condition on the health of individuals. This has been the great challenge in the area of bone metabolism.

Could normocalcemic primary hyperparathyroidism be an indolent disease or could it have an impact similar to classic primary hyperparathyroidism on bone metabolism and with renal involvement? It is extremely important to conduct studies on this pathological condition in order to achieve a more precise epidemiological characterization and definition of the clinical significance of this disorder.

\section{PATIENTS AND METHODS}

\section{Selection of patients and study design}

A survey was conducted using the database from the Center for Endocrinology and Bone Metabolism of Pernambuco, Recife, Brazil. From this database, the records of 179 women who came to the hospital to be screened for osteoporosis were analyzed.

The following cases were excluded from the analysis: patients taking bisphosphonates, diuretics, anticonvulsants and lithium; as well as those suffering from kidney failure with GFR $<40 \mathrm{~mL} / \mathrm{min}$, using the formula Modification of Diet in Renal Disease Study (MDRD); 25-hydroxy vitamin D $<30$ $\mathrm{ng} / \mathrm{mL}$; metabolic bone diseases (e.g., classic primary hyperparathyroidism); gastroenterological diseases associated with malabsorption; liver disease and those whose records were incomplete (3).

One hundred and fifty-six patients were eligible for the study, and the following measurements had been recorded in all cases: at least two samples of serum total calcium (normal range: 8.5 to $10.4 \mathrm{mg} / \mathrm{dL}$ ), serum PTH (normal range between 10 and $65 \mathrm{pg} / \mathrm{mL}$ ), 25-hydroxy vitamin D (25OHD, normal > $30 \mathrm{ng} /$ $\mathrm{mL}$ ) and C-telopeptide (normal: 50-450 pg/mL). Bone mineral density (BMD) and T-scores were evaluated by the DXA technique (Lunar Corpora- tion Madison, Wisconsin, USA) in the lumbar spine (Ll-L4), femoral neck and distal one-third of the radius. The latter measurement was only recorded in patients with primary hyperparathyroidism. Correction of serum calcium in relation to albumin levels was performed using the formula: corrected calcium = calcium recorded $+(4-$ serum albumin $)$ x 0.8 .

Analyses of serum albumin, calcium and creatinine were measured by dry chemistry in VITROS 250/950 (Johnson \& Johnson $^{\circledR}$ ). PTH levels were measured by means of chemiluminescence in Immulite 200, which shows intra- and inter-assay coefficients of variation of $4.2 \%$ to $5.7 \%$ and $6.3 \%$ to $6.8 \%$, respectively. Serum $\beta$-CTX levels were measured by electrochemiluminescence (Elecsys systems, Roche diagnostics, Mannheim, Germany). The measurement interval was 10-6,000 $\mathrm{pg} / \mathrm{mL}$, with the lowest detection threshold equal to $10 \mathrm{pg} / \mathrm{mL}$, and intra- and inter-assay coefficients of variation of $10 \%$ and $12 \%$, respectively. Concentration of $25 \mathrm{OHD}$ was determined by competitive chemiluminescent immunoassay (DiaSorin-Liaison), which has a coefficient of variation of $10 \%$, and the following reference values: normal, 30 to $60 \mathrm{ng} / \mathrm{mL}$; borderline, 20 to $30 \mathrm{ng} / \mathrm{mL}$; insufficient, 10 to $20 \mathrm{ng} / \mathrm{mL}$; poor, less than $10 \mathrm{ng} / \mathrm{mL}$.

Nephrolithiasis and bone fractures were documented based on a review of the medical records. The retrospective review of medical records for the purposes of this study was approved by the board of directors and Ethics Committee of the hospital.

\section{Statistical analysis}

Analysis of absolute data and percentage distributions was done by mean of descriptive statistics, and presented as mean and standard deviations. Fisher's exact test was used when the conditions were not right for chi-square test, and Student's $t$-test was employed for equal or unequal variances (inferential statistics). Levene $\mathrm{F}$ test was used to verify the equality of variances.

The level of significance adopted for the statistical tests was 5.0\%. Data were entered on an Excel spreadsheet, and statistical calculations were done in SPSS 15.0 (Statistical Package for Social Sciences).

\section{RESULTS}

A total of 156 women from a database were evaluated, after excluding those cases that did not meet the inclusion criteria. All had come to the Endocrinology and 
Bone Metabolism reference center to be screened for osteoporosis. Fourteen patients with normocalcemic hyperparathyroidism were identified, representing $8.9 \%$ of the study population. Baseline characteristics of all patients are shown in Table 1.

Table 1. Baseline characteristics and biochemical data of patients with and without NPHPT

\begin{tabular}{lccc}
\hline & HPTN & $\begin{array}{c}\text { Without } \\
\text { HPTN }\end{array}$ & p \\
\hline Age (years) & $60.6 \pm 14.8$ & $62.4 \pm 10.5$ & 0.664 \\
Time since menopause (years) & $13.8 \pm 13.6$ & $14.6 \pm 10.4$ & 0.777 \\
BMI (kg/m²) & $25.0 \pm 3.1$ & $25.6 \pm 3.6$ & 0.559 \\
PTH (pg/mL) & $109.5 \pm 45.2$ & $39.1 \pm 14.3$ & $<0.001$ \\
Serum calcium (mg/dL) & $9.4 \pm 0.4$ & $9.5 \pm 0.4$ & 0.765 \\
CTX (pg/mL) & $328.7 \pm 142.2$ & $342.0 \pm 230.0$ & 0.759 \\
25 (OH) vitamin D (pg/mL) & $41.5 \pm 10.3$ & $29.5 \pm 16.0$ & $<0.001$ \\
BMD lumbar spine $\left(\mathrm{g} / \mathrm{cm}^{2}\right)$ & $0.97 \pm 0.2$ & $1.0 \pm 0.1$ & 0.511 \\
BMD femoral neck $\left(\mathrm{g} / \mathrm{cm}^{2}\right)$ & $0.74 \pm 0.1$ & $0.78 \pm 0.1$ & 0.236 \\
\hline
\end{tabular}

In the overall analysis, mean age was 62.2 years. Only one patient was of childbearing age, the others were menopausal for an average of 14.5 years. Mean BMI was $25.5 \mathrm{~kg} / \mathrm{m}^{2}$ and there were no statistical differences between those with normocalcemic hyperparathyroidism and the other patients. Overall mean serum calcium, corrected for albumin, was 9.4 $\mathrm{mg} / \mathrm{dL}$ in the group with normocalcemic hyperparathyroidism, a value similar to that of the patients without the disorder, which was $9.5 \mathrm{md} / \mathrm{dL}$. In the assessment of 25-hydroxy vitamin D status, excluding the group with normocalcemic hyperparathyroidism - in which $25 \mathrm{OHD}$ deficit was an exclusion criterion $-26.1 \%$ of the patients had levels below $20 \mathrm{ng} / \mathrm{mL}$, and $62 \%$ had levels below $30 \mathrm{ng} / \mathrm{mL}$.

The analysis of serum PTH showed mean values of $39.1 \mathrm{pg} / \mathrm{mL}$ and $109.5 \mathrm{pg} / \mathrm{mL}$ in the groups without and with normocalcemic hyperparathyroidism, respectively $(\mathrm{p}=0.001)$. Serum levels of C-telopeptide were similar in both groups.

There were no statistical differences in relation to bone mineral density of the lumbar spine and femoral neck (Table 1). Of the 14 patients affected, five $(35.7 \%)$ had osteoporosis in at least one of the three sites evaluated, according to diagnostic criteria of the World Health Organization (WHO). Osteoporosis was most common in the lumbar spine $(28.5 \%)$ and distal one-third of the radius $(28.5 \%)$, with $21.4 \%$ of patients affected in the femoral neck. In patients with normocalcemic hyperparathyroidism, mean bone mineral density in the distal one-third of the radius was $0.580 \mathrm{~g} / \mathrm{cm}^{2}\left( \pm 0.110 \mathrm{~g} / \mathrm{cm}^{2}\right)$, and mean T-score was -1.97.

In the medical records, kidney stones were reported in $28.6 \%$ of the women with NPHPT, in contrast to only $0.7 \%$ in the noncarriers $(\mathrm{p}<0.001)$. Regarding the presence of general fractures, $21.4 \%$ of the patients with NPHPT were affected versus $16.2 \%$ in the noncarriers $(\mathrm{p}=0.705)$. Fractures were observed in three women with NPHPT, one in the lumbar spine, one in the humerus, and the other in the wrist.

\section{DISCUSSION}

The present study demonstrated a prevalence of $8.9 \%$ of normocalcemic hyperparathyroidism in a sample of women referred to a reference center for osteoporosis screening. There are very few data in the literature regarding this condition. In a population-based study in Sweden, prevalence of normocalcemic hyperparathyroidism among postmenopausal women was $0.6 \%$ (4).

In fact, NPHPT clinical condition has not been well characterized yet, and it remains unclear whether it could be merely an incipient and indolent form of classic hyperparathyroidism $(5,6)$.

It has been suggested that normocalcaemia does not accurately reflect the biologically active free fraction of calcium in these patients, making it essential to assay ionized calcium levels. Subsequently, it was shown that even when this laboratory technique was used, cases of normocalcemia persisted $(7,8)$.

Rao and cols. proposed a biphasic progression towards the hypercalcemic form of the disease, with an early, subclinical phase with normal serum calcium levels, during which some features of the disease might be detected, but with no progression (9). A study by Bilezikian and cols., corroborated this finding, and reported that the analysis of bone mineral density in trabecular and cortical areas, and biochemical tests showed the disease to be stable for over a decade $(10,11)$.

After this initial phase, the disease is said to progress to its classic form, with a rise in serum calcium levels, and greater abundance of clinical findings. It is important to emphasize that this disease model proposed by Rao and cols. is not a definitive one. Further studies are needed to substantiate this hypothesis (12). 
A more recent study, conducted by Maruani and cols., in 2003, demonstrated that a significant proportion of patients with normocalcemic hyperparathyroidism have lower kidney and bone sensitivity to the biological effect of PTH. The explanation for this lower sensitivity needs further investigation (13).

With the increasing medical concern on bone health, some specialists in bone metabolism routinely perform PTH measurement when there is a decrease in bone mineral density, making it possible to identify patients with normocalcemic hyperparathyroidism. The main issue now is whether normocalcemia is a guarantee of the indolent nature of this clinical condition.

Kidney stones were found in $28.6 \%$ of the women with normocalcemic hyperparathyroidism. It is therefore possible that NPHPT has a phenotype similar to that of the classic form of the disease, which leads us to believe that this clinical condition may cause some adverse health outcomes, deserving greater attention.

In the study by Lowe and cols., involving 37 patients with NPHPT, $11 \%$ had fractures and $2.5 \%$ had kidney stones, which is less than we found in our study. They found osteoporosis in $57 \%$ of the patients versus $35.7 \%$ of our patients. They also demonstrated that the sites preferentially affected by osteoporosis were the femoral neck and lumbar spine, unlike the results of our study, in which the most affected site was the distal one-third of the radius (3).

In conclusion, our data suggest that NPHPT has a diverse phenotypic presentation, which may resemble, in some way, the hypercalcemic form of primary hyperparathyroidism. As this was a retrospective study based on medical records, further studies are needed to support this conclusion.

Disclosure: no potential conflict of interest relevant to this article was reported.

\section{REFERENCES}

1. Silverberg SJ, Bilezikian JP. Primary hyperparathyroidism. Endocrinology. 2001;1075-93.

2. Silverberg SJ, Lewiecki EM, Mosekilde L, Peacock M, Rubin MR. Presentation of asymptomatic primary hyperparathyroidism: proceedings of the third international workshop. J Clin Endocrinol Metab. 2009;94(2):351-65.

3. Lowe H, McMahon DJ, Rubin MR, Bilezikian JP, Silverberg SJ. Normocalcemic primary hyperparathyroidism: further characterization of a new clinical phenotype. J Clin Endocrinol Metab. 2007;92:3001-5.

4. Lundgren E, Rastad J, Thurfjell E, Akerstrom G, Ljunghall S. Population based screening for primary hyperparathyroidism with serum calcium and parathyroid hormone values in menopausal women. Surgery. 1997;121:287-94.

5. Bilezikian JP, Potts JT. Asymptomatic primary hyperparathyroidism: new issues and new questions bridging the past with the future. J Bone Miner Res. 2002;17(suppl 2):N57-67.

6. Glendenning P, Gutteridge DH, Retallack RW, Stuckey BG, Kermode DG, Kent GN. High prevalence of normal total calcium and intact PTH in 60 patients with proven primary hyperparathyroidism. Aust N Z J Med. 1998;2:173-8.

7. Forster J, Monchik JM, Martin HF. A comparative study of serum ultrafiltrable, ionized, and total calcium in the diagnosis of primary hyperparathyroidism in patients with intermittent or no elevation in total calcium. Surgery. 1988;04:1137-42.

8. Muldowney FP, Freaney R, McMullin JP, Towers RP, Spillane A, $\mathrm{O}^{\prime}$ Connor $\mathrm{P}$, et al. Serum ionized calcium and parathyroid hormone in renal stone disease. Q J Med. 1976;45:75-86.

9. Rao DS, Wilson RJ, Kleerekoper M, Parfitt AM. Lack of biochemical progression or continuation of accelerated bone loss in mild asymptomatic primary hyperparathyroidism. J Clin Endocrinol Metab. 1988;67:1294-8.

10. Parfitt AM, Rao DS, Kleerekoper M. Asymptomatic primary hyperparathyroidism discovered by multichannel biochemical screening: clinical course and considerations bearing on the need for surgical intervention. J Bone Miner Res. 1991;6(Suppl 2):S97-S101; discussion S121-4.

11. Silverberg SJ, Shane E, JacobsTP, Siris E, Bilezikian JP. A 10-year prospective study of primary hyperparathyroidism with or without parathyroid surgery. N Engl J Med. 1999;341:1249-55.

12. Silverberg SJ, Bilezikian JP. "Incipient" primary hyperparathyroidism: a "forme fruste" of an old disease. J Clin Endocrinol Metab. 2003;88(11):5348-52.

13. Maruani G, Hertig A, Paillard M, Houillier P. Normocalcemic primary hyperparathyroidism: evidence for a generalized target-tissue resistance to parathyroid hormone. J Clin Endocrinol Metab. 2003;88(10):4641-8. 